\title{
A POSSIBILIDADE DE DESCONSTITUIÇÃO DA PATERNIDADE HAVIDA POR RECONHECIMENTO
}

\section{THE POSSIBILITY OF DESCONSTITUTION OF PATERNITY ACKNOWLEGDMENT}

\author{
${ }^{1}$ Maria Amélia da Costa
}

\section{RESUMO}

As questões relacionadas às possibilidades da desconstituição da paternidade surgem em razão tanto do avanço científico, que permite a prova pericial conclusiva de DNA, quanto da observação do princípio da socioafetividade como princípio basilar do Direito de Família. Estabelecida como irrevogável pela lei civil, poderia a paternidade havida por reconhecimento ser desconstituída além da hipótese de erro? O presente trabalho ressalta a necessidade da reflexão principiológica na solução destas demandas, em especial da aplicação do princípio da afetividade e da paternidade responsável, apresentando, para isso, um panorama da filiação no Direito brasileiro e um caso concreto como exemplo.

Palavras-chave: Direito de família contemporâneo, Paternidade, Filiação, Socioafetividade

\begin{abstract}
The issues over possibilities of reversal of paternity acknowledgment emerge due the scientific advance, which makes possible conclusive proofs through DNA, as much as the observation of the socioaffectiviness as a fundamental principal on Family Law. Established as irrevocable by civil law, would filiation firmed by recognition be voided beyond the assumption of an error? This current article highlighs the need of principiologic reflection on the solution of such demanding, specially the application of the principle of affectiveness and responsible parenthoood, through the presentation of an overview of filiation in the Brazilian law and a concrete case as example.
\end{abstract}

Keywords: Contemporery family law, Paternity, Filiation, Social-affectiveness

\footnotetext{
${ }^{1}$ Mestra em Direito pela Universidade Estácio de Sá - UNESA, São Paulo, Brasil. Professora supervisora e advogada do Núcleo de Prática Jurídica da Universidade Presidente Antônio Carlos - UNIPAC, Minas Gerais, MG. (Brasil). E-mail: mariaameliadacosta@ hotmail.com.
} 


\section{INTRODUÇÃO}

A definição jurídica da filiação, não apenas de seu conceito, mas especialmente do modo pelo qual é construída, é tema de constante desafio para o Direito contemporâneo, nesses tempos em que a família assume contornos diversos daquele modelo patrimonializado do passado. Hoje, a família é vista como uma rede de relações humanas baseada no afeto, convivência mútua e realização pessoal de cada um dos seus membros.

Assumindo esses novos contornos, a disciplina da filiação estabelecida pela lei civil já se mostra insuficiente para lidar com as mudanças trazidas por esta nova visão da família. Socorre-se assim, da Constituição Federal, que por sua sólida base principiológica, oferece fundamentos para decisões judiciais em demandas novas, que surgem em razão da complexidade das relações familiares na atualidade. A Constituição Federal, por exemplo, permite a observação da afetividade, fundada no princípio da dignidade da pessoa humana, do qual é extraído o princípio da socioafetividade, que vem pautando os julgados nas ações em que se discute a filiação.

Em razão também da complexidade das relações familiares, as possibilidades de desconstituição da relação de paternidade parecem já não caber mais nos modelos previstos. Hoje, no que tange à paternidade estabelecida através do reconhecimento de filho, que, por previsão legal, irrevogável, a manutenção deste vínculo transita entre a responsabilidade nascida a partir de sua constituição e a relação de afeto estabelecida entre o pai e o filho. As possibilidades de desconstituição da paternidade pelo reconhecimento não se restringiriam mais às hipóteses de erro, como foram outrora.

Necessária se faz, portanto, a discussão acerca da possibilidade da desconstituição da filiação havida por meio de reconhecimento através de uma ação negatória de paternidade, tendo em vista a característica de irrevogabilidade que a lei lhe impõe. A observar o esforço principiológico contidos nos julgados, verifica-se que a paternidade estabelecida através do reconhecimento de filho não tem mais como ser considerada como um vínculo irretratável.

O presente trabalho é apresentado ao XXV Encontro Nacional do CONPEDI e foi desenvolvido dentro da temática apresentada - Direito e desigualdades: diagnósticos e perspectivas para um Brasil justo, ressaltando a necessidade da reflexão principiológica na solução das demandas familiares, para que não se mantenha, nem tampouco se desconstitua, injustamente as relações de filiação.

A tutela jurídica relações de paternidade/filiação vem passando por uma série de modificações, pode-se dizer nas últimas quatro décadas, em razão dos avanços científicos 
especialmente a fertilização in vitro e o teste genealógico de DNA, que modificaram completamente o paradigma da determinação biológica da paternidade. A ciência se conecta com o Direito ora dando oportunidade a casais inférteis a se valer de doadores, que de plano já tem a paternidade afastada, ora confirmando o vínculo biológico, como a utilização do exame genealógico de DNA, que tem servido como prova definitiva na determinação da paternidade.

Mas não é apenas no amparo científico que a tutela das relações de paternidade/filiação vem experimentando avanços. Mais recentemente, em razão da observação do princípio da afetividade, vínculos familiares nem sempre confirmados biologicamente vem sendo mantidos ou desconstituídos. O princípio da afetividade chega a ir além dos avanços científicos pois enquanto estes encontram seus principais obstáculos nas lacunas legais, aquele desafia a própria lei, ensejando julgados contrários à sua letra, porém fundados numa base principiológica que busca ser mais justa.

O presente trabalho vem estruturado em quatro capítulos, sendo o primeiro destinado a um panorama da filiação no Direito brasileiro, explicando suas formas de constituição pelo Direito Civil. O segundo capítulo traz considerações específicas acerca da filiação havida no casamento e o terceiro, acerca da filiação havida em relações diferentes do casamento. Por fim, o quarto capítulo questiona a possibilidade da utilização da ação negatória de paternidade nos casos de filiação havida em relações diferentes do casamento, partindo de um exemplo de caso.

O objetivo geral do presente trabalho é apresentar questionamentos e possibilidades a respeito da desconstituição da paternidade havida por reconhecimento, levando em conta as soluções apresentadas pela lei civil e os princípios constitucionais, especialmente o princípio da socioafetividade. O objetivo específico é verificar se a ação negatória de paternidade, prevista pelo Código Civil como a ação destinada a afastar a paternidade havida no casamento, pode ser utilizada nos casos de filiação havida por reconhecimento, desafiando a irrevogabilidade desta espécie de filiação.

\section{A FILIAÇÃO NO DIREITO BRASILEIRO}

Segundo Pontes de Miranda (1954, p.19), “a relação que o fato da procriação estabelece entre duas pessoas, uma das quais nascida da outra, chama-se paternidade, ou maternidade, quando considerada em relação ao pai ou à mãe, e filiação, quando em relação 
ao filho para com qualquer um dos genitores. " A filiação também é o vínculo primeiro do parentesco. Em assim sendo, a relação primeira e mais importante de parentesco que se estabelece é a do pai, ou da mãe, com seu filho (GONÇALVES, 2015).

Parentesco tem por definição a relação existente entre seres descendentes de um mesmo tronco comum, sendo essa definição aplicada a qualquer estudo da família, pelo Direito ou por outras ciências. O parentesco é um conceito da biologia tomado de empréstimo pelo Direito, que disciplina as relações interpessoais daqueles componentes de uma mesma família. Assim, a paternidade tende a ser vista tanto como um fato biológico quanto um fato jurídico, social e cultural. Segundo Villela:

Terá sido a precedência histórica da natureza sobre a cultura que fez da paternidade, desde os tempos mais remotos, um conceito primária quando não prevalentemente biológico. [...] A paternidade, como conceito, poderia ter-se formado nessa linha de acomodação que, partindo do fato biológico, então incontrolável, chegava aos rudimentares predicamentos sociais, jurídicos e religiosos, que lhe garantiam um lugar ao sol o insipiente thesaurus da cultura. A origem radicaria, assim, em pura base biológica. Note-se, entretanto, que a paternidade, em si mesma, não é um fato da natureza, mas um fato cultural. (VILLELA, 1991, p. 400-401)

Mas além do vínculo biológico, o Direito considera também outros vínculos, como aqueles derivados de uma transmissão de pátrio poder, que seria o caso da adoção, e aquele decorrente do casamento, que é o parentesco por afinidade (FRANÇA, 1999). O Direito não pode, nem ignora, o fato biológico, mas possibilita e garante proteção a vínculos de filiação estabelecidos através outras origens, como é o caso da adoção, vínculo que atualmente deriva de uma sentença judicial, ou da inseminação artificial. A respeito da formação do vínculo por inseminação artificial, Sílvio de Salvo Venosa explica:

Todo ser humano possui pai e mãe. Mesmo a inseminação artificial ou as modalidades de reprodução assistida não dispensam o progenitor, o doador, ainda que essa forma de paternidade não seja imediata. Desse modo, o Direito não pode se afastar da verdade científica. A procriação é, portanto, um fato natural (VENOSA 2011, p. 223).

Para o Direito, portanto, a filiação não se restringe apenas ao vínculo biológico. E uma vez que as relações sociais em que duas pessoas vivem e se comportam como sendo pai/mãe e filho se estabelecem, para além dos vínculos genéticos, o Direito é provocado a apresentar respostas, visto que a todo momento estes outros vínculos podem ser questionados judicialmente. Nestes casos, embora inexistente o vínculo genético, ocorrem diversas outras 
manifestações - cuidado, afeto, manutenção e posse do estado de filho - que acabam por ensejar a mesma proteção legada aos parentes e filhos consanguíneos.

No que diz respeito à construção jurídica da filiação, esta não parte de uma determinação apriorística da filiação pelo vínculo biológico ou por outro vínculo. Com exceção da adoção, que é um vínculo de filiação determinado através de uma sentença judicial, ainda hoje toda a sistemática legal da filiação acaba por seguir a instituição sobre a qual o direito de família se estruturou, e até hoje em muitos aspectos se estrutura: o casamento. Desta forma, excluindo-se a adoção, ainda se estuda a filiação dividindo-a em duas espécies: aquela havida numa relação entre duas pessoas casadas e aquela proveniente quaisquer outras formas diferentes do casal heterossexual casado.

A construção jurídica da filiação estando atrelada à estrutura do casamento faz admitir situações em que se presume, e uma presunção que admite prova em contrário, que o pai do filho da mulher casada é o seu marido. Pater is est quem justiae nuptiae demonstrant, ou seja, pai é aquele que comprovadamente é casado com a mãe, é a presunção de que o marido da mãe é o pai do filho que ela gera e pare, em todas as situações descritas no artigo 1597 do Código Civil ${ }^{1}$.

Esta construção, denominada por Fachin (1992) como critério nupcialista da paternidade, é, como posto por Maria Berenice Dias (2013, s/p), um resquício da "visão sacralizada da família e da necessidade de sua preservação a qualquer preço, nem que para isso tenha de atribuir filhos a alguém, não por ser pai ou mãe, mas simplesmente para a mantença da estrutura familiar. "A razão destas presunções é a manutenção da moral familiar, a "meta histórica relativa à ordem social" (SILVA, 2013, p.147), priorizando um critério jurídico no lugar de um critério biológico, como reconhecimento de uma espécie de supremacia da relação de casamento.

Por outro lado, embora a lei ainda mantenha essa estrutura definida a partir do casamento, ou seja, sendo uma filiação derivada do casamento, estabelecida pela presunção, e outra a estabelecida pelo reconhecimento, toma importância o critério socioafetivo, tanto para

\footnotetext{
${ }^{1}$ Art. 1.597. Presumem-se concebidos na constância do casamento os filhos:

I - nascidos cento e oitenta dias, pelo menos, depois de estabelecida a convivência conjugal;

II - nascidos nos trezentos dias subsequentes à dissolução da sociedade conjugal, por morte, separação judicial, nulidade e anulação do casamento;

III - havidos por fecundação artificial homóloga, mesmo que falecido o marido;

IV - havidos, a qualquer tempo, quando se tratar de embriões excedentários, decorrentes de concepção artificial homóloga;

V - havidos por inseminação artificial heteróloga, desde que tenha prévia autorização do marido.
} 
caracterização de vínculos já previstos pela lei quanto para o estabelecimento de uma outra forma de vínculo, exclusivamente baseado no afeto. Como advertido por Fachin:

O critério socioafetivo é, reconhecidamente, modo de estabelecimento da paternidade. Ao mesmo tempo em que a presunção pater is est deixa de ser dogma, como já escrevemos, o dado socioafetivo passa a ser um dos elementos de maior relevância para a determinação da paternidade/maternidade. (FACHIN, 2008, p.154)

Este critério socioafetivo, pelo qual o vínculo familiar se estabelece em razão laços de afeto entre os membros da família, fortalece suas raízes a partir da Constituição Federal de 1988 em especial com o reconhecimento da união estável como uma forma de constituição familiar, caracterizada pela intenção da formação de família e pela relação de afeto entre o par. Só que a interferência do afeto nas relações jurídicas, elevado a princípio da socioafetividade não ficou apenas na relação básica do par formador da família, mas se estendeu também aos laços de parentesco, especialmente à filiação.

A Constituição Federal deu outra dimensão ao conceito de família, que passa a importar mais à realização e à valorização da pessoa humana. Como afirma Cristiano Cassetari:

[...] podemos afirmar que a família moderna possui amparo no princípio da solidariedade, insculpido no artigo $3^{\circ}$, inciso I, da Constituição Federal, que fundamenta a existência da afetividade em seu conceito e existência e dá à família uma função social importante, que é a de valorizar o ser humano. Dessa forma, quando a família passa a realizar e concretizar a afetividade humana, ela desloca as funções econômica, política e religiosa para a afetiva, para determinar a repersonalização das relações civis, que valoriza mais o interesse humano do que as relações patrimoniais, em que a pessoa está no centro do Direito, no lugar do patrimônio. (CASSETARI, 2014, p. 28)

O elemento socioafetivo identificado nas questões familiares passou a ser expressão máxima da importância da dignidade da pessoa humana para o Direito Civil. Nas palavras de Luiz Edson Fachin:

Parece inequívoco que, contemporaneamente, o elemento socioafetivo se apresenta como o de maior relevância na análise das questões atinentes ao direito de família, pelo que sua repercussão nas relações atinentes à filiação é consequência natural, verdadeiro corolário lógico de uma nova racionalidade que coloca a dignidade da pessoa humana como centro das preocupações do direito civil. (FACHIN, 2008, p.155)

Toda a normatização da filiação experimentou uma mudança definitiva com a Constituição Federal, que previu, em seu artigo 227, § 6. , a igualdade entre os filhos. Ou seja, 
a partir daquele momento, não importava mais o tipo de relação que deu origem àquele filho para conferir-lhe status e direitos. Apenas um status passou a ser possível: o de filho. Não havia mais o que se falar de filho legítimo, filho ilegítimo, natural, incestuoso ou, ainda, filho adotivo, categorias que por muito tempo determinaram diferenças de tratamento jurídico, principalmente no tocante aos direitos sucessórios.

Afastada, pois, em definitivo, a desigualdade entre os filhos pela Constituição Federal, sendo o $\S 6^{\circ}$ do artigo 227 literalmente repetido no caput do artigo 1596, inaugurando o capítulo da filiação no Código Civil, o status de filho passou a ser único e sem distinções. Entretanto, a disciplina jurídica desta filiação ainda guarda diferenças que podem surtir efeitos relevantes tanto nas vidas dos pais quanto na dos filhos. Esta disciplina da filiação, mais uma vez lembrando-se da exceção da adoção ${ }^{2}$, é normatizada, pois, a partir da existência ou não do casamento.

Assim, muito embora tenha a Constituição Federal extinto o modelo que determinava diferença entre os filhos de acordo com a origem da filiação, o sistema de determinação em si ainda é diferenciado: a filiação havida no casamento operando sobre a lógica patriarcal, em que mãe e filho são subordinados a um pai, em razão do vínculo do casamento (LEITE, 2004), e a filiação havida fora do casamento se dando única e exclusivamente através do reconhecimento, cada uma com suas características próprias.

3 A filiação havida no casamento - a presunção pater is est e a ação negatória de paternidade

O estabelecimento da filiação havida no casamento difere-se de sobremaneira da havida fora no casamento, principalmente em razão da presunção pater is est, ou seja, de que o pai do filho da mulher casada é o seu marido. Segundo Maria Berenice Dias:

Essa verdade tem uma função pacificadora, pois elimina a incerteza do marido em relação aos filhos de sua esposa. Pai é aquele que o sistema jurídico define como tal. Sua finalidade é fixar o momento da concepção de modo a definir a filiação, certificar a paternidade e os direitos e deveres decorrentes. Portanto, a filiação matrimonial decorre de uma ficção jurídica: o pai sempre é o marido da mãe. Desse modo, os filhos de pais casados têm, e de pleno direito, estabelecidas maternidade e paternidade. (DIAS, 2013, s/p)

\footnotetext{
${ }^{2}$ Neste trabalho não serão feitas considerações a respeito da adoção pois o problema abordado não diz respeito a este tipo de filiação.
} 
Essa presunção, segundo a autora, nem é exatamente do fato da filiação em si, mas da fidelidade da mulher ao marido. Sendo a fidelidade um dever do casamento, admite-se que o filho da mulher casada é presumidamente de seu marido, pois esta não poderia ter gerado filho de outro homem. Pontes de Miranda corrobora o raciocínio, considerando:

Tal presunção de que o filho concebido na constância da sociedade conjugal tem por pai o marido de sua mãe possui, como fundamento, o que mais ordinariamente acontece: a fidelidade conjugal por parte da mulher. Praesemptio sumitur ex eo quod plerumque fit. Presumida a fidelidade da mulher, a paternidade torna-se certa. (MIRANDA, 1954, p. 24)

Esta espécie de filiação é denominada por Maria Helena Diniz como filiação matrimonial; nas palavras da autora "[...] considerando aqui, uma dupla presunção: a de coabitação e fidelidade da mulher e a de reconhecimento implícito e antecipado da filiação feito pelo marido ao se casar[...]" (DINIZ, 2011, p. 482).

A presunção pater is est tem suas hipóteses estabelecidas nos incisos do artigo 1597 do Código Civil. Nos incisos I e II, há referência expressa à constância da convivência conjugal, sendo estabelecidos prazos que justificariam a presunção, de acordo com um nascimento dentro do termo de viabilidade de sobrevivência de um ser humano gerado.

Outras presunções estabelecidas pelo Código Civil no artigo 1597, referem-se à fecundação artificial homóloga, ou seja, uma fecundação feita fora do corpo da mulher, com gametas pertencentes a ela e ao seu marido, tendo ocorrido a concepção na constância do casamento (inciso III) ou após a morte do marido (inciso IV), e à fecundação artificial heteróloga, em que um ou os dois gametas não pertençam aos pais do filho gerado (inciso IV). Neste caso, que exige a autorização do marido, este realiza o reconhecimento antes mesmo da fecundação, admitindo que o filho não seja seu filho biológico, ou não seja filho biológico de sua mulher. Esta última hipótese, inclusive, é defendida por alguns autores, como Guilherme Calmon Nogueira da Gama (apud DINIZ, 2011), como não impugnável, em razão do princípio da paternidade responsável, previsto no $§ 70^{\circ}$ do artigo 226 da Constituição Federal, constituindo uma presunção iure et iure. No mesmo sentido, Flavio Tartuce:

De início, pontue-se que o dispositivo atual não se aplica aos casos de inseminação artificial heteróloga autorizada pelo marido, até porque não há o vínculo biológico entre o pai que registrou e o filho. Repise-se que esse é o teor do Enunciado n. ${ }^{\circ} 258$ do CFJ/STJ, da III Jornada de Direito Civil: "Não cabe ação prevista no art. 1601 do Código Civil se a filiação tiver origem em procriação assistida heteróloga, autorizada pelo marido, nos termos do inciso V do artigo 1597, cuja paternidade configura presunção absoluta. (TARTUCE, 2016, p.425) 
Na ocasião do registro, estando amparada pela presunção, pode a mulher casada ser a declarante, estabelecendo tanto a maternidade quanto a paternidade. Comprovando o casamento pela respectiva certidão, ela fica amparada pelo parágrafo $2{ }^{\circ}$ do artigo 54 da Lei de Registros Públicos, Lei n. ${ }^{\circ} 6015$ de 1973, que garante que o nome do pai só pode ser lançado no registro do nascimento quando a mãe é declarante nos termos da legislação civil vigente, ou seja, configurada uma das hipóteses de presunção.

Ao contrário, o mesmo não ocorre com a mulher não casada. O mesmo dispositivo retro citado diz que o nome do pai constante na declaração de nascido vivo não constitui prova nem presunção de paternidade. Esta mulher, portanto, ao registrar seu filho, apenas informa quem é o pai, não podendo registrá-lo no nome deste. Nestes casos, haverá uma averiguação posterior desta paternidade, para que o pai reconheça o filho de maneira voluntária ou através de uma ação investigatória de paternidade.

Maria Berenice Dias defende que, havendo prova pré-constituída da união estável, a presunção pater is est também a ela deve ser estendida:

[...] havendo prova pré-constituída da união, como decisão judicial declarando sua vigência no período coincidente com a época da concepção, é imperioso admitir dita presunção. Não se pode desprezar uma sentença de união estável e lhe emprestar menos valor do que a uma certidão de casamento. (DIAS 2013, s/p)

O sistema das presunções de paternidade admite provas em contrário, como, por exemplo, a prova da impotência generandi, prevista no artigo 1599 do Código Civil. Mas este sistema acabou por ser desconstruído a partir da popularização do exame de DNA, que possibilitou a prova da paternidade, ou da não paternidade, com uma margem de erro insignificante. A respeito, diz Zeno Veloso

Toda a cultura, a construção doutrinária, a jurisprudência, enfim, toda a concepção sobre a prova nas ações de filiação, que tinha por base a circunstância de que a paternidade era um mistério impenetrável, sendo possível obter-se a prova direta da mesma, passou, recentemente, por radical transformação, e um entendimento de séculos teve de ser inteiramente revisto. Com o progresso científico e a invenção do teste DNA (ácido desoxirribonucleico), a paternidade pode ser determinada com absoluta certeza (VELOSO apud TARTUCE, 2016, p. 404)

Desta forma, ao homem casado ficou mais fácil provar que o filho de sua mulher não é seu filho, se é seu desejo afastar, em definitivo, esta paternidade. E como a lei, pela presunção pater is est, atribui ao marido da mulher casada a paternidade de seu filho, ainda que não seja o pai biológico, é sua a legitimidade ativa para a ação negatória de paternidade. 
Prevista no artigo 1601 do Código Civil, a ação negatória de paternidade é aquela através da qual o marido da mulher pretende afastar a paternidade do filho registrado em seu nome, por sabê-lo ou ter dúvidas de que não é seu. Tal ação é personalíssima, só podendo intentá-la o homem que estava casado com a mãe à época da presunção, podendo, caso faleça, ter prosseguimento com seus herdeiros, assumindo seu lugar no polo ativo, uma vez que dela decorrem efeitos sucessórios.

É também imprescritível, uma vez que o Código Civil de 2002 optou pela imprescritibilidade das ações de estado. Esta imprescritibilidade não deixou de merecer críticas da doutrina. Eduardo de Oliveira Leite (2005) esclarece que no Código Civil Brasileiro de 1916, a ação negatória de paternidade tinha prazo prescricional de dois meses, caso o pai estivesse presente no momento do nascimento do filho e de três meses, caso estivesse ausente. Para o autor, o prazo prescricional justificava-se, pois, após este tempo haveria o estabelecimento de um vínculo familiar afetivo, que não merecia mais ser desfeito:

\begin{abstract}
A finalidade da lei não era, como poder-se-ia imaginar em exegese reducionista, apenas afirmar a presunção pater is est, com mero objetivo de tutelar a família legítima, mas também a de proteger a criança que, após o decurso do prazo, se via inserida na malha familiar, de modo definitivo. (LEITE, 2005, p. 212)
\end{abstract}

De certa maneira, o Código Civil Brasileiro de 1916 garantia a estabilidade familiar ao mesmo tempo que, propositalmente ou não, resguardava os direitos decorrentes da relação afetiva estabelecida entre o pai e o filho. Rodrigo da Cunha Pereira (apud TARTUCE, 2016) também critica a imprescritibilidade por desprezar a filiação socioafetiva, privilegiando o vínculo biológico.

O Código Civil atual, portanto, ainda diferencia a filiação havida no casamento das demais espécies. A ela estabelece presunções que seguem a lógica do casamento institucionalizado, ou seja, aquele a que o Estado dá certeza da existência e que tem deveres a serem cumpridos, especialmente o dever de fidelidade. A paternidade havida no casamento é imposta ao marido da mãe, através de presunções, fundadas, como visto, na fidelidade da mulher ao homem. Para estas presunções, por conseguinte, admite-se produção de prova em contrário, no curso de uma ação negatória de paternidade.

\title{
4 A FILIAÇÃO HAVIDA EM RELAÇÕES DIFERENTES DO CASAMENTO
}

Os filhos havidos em relações diferentes do casamento não têm a filiação estabelecida pelas presunções derivadas do vínculo entre seus pais, como é o caso dos filhos 
de pais casados. Para estes, o vínculo de filiação será estabelecido através do reconhecimento, que se dá de forma espontânea, nas formas do artigo 1609 do Código Civil, ou de forma forçada, através de uma sentença em ação de investigação de paternidade, podendo, nos casos de reconhecimento espontâneo, coincidir ou não com o vínculo biológico. O reconhecimento é, pois, um ato declaratório: "O reconhecimento vem a ser o ato que declara a filiação havida fora do matrimônio, estabelecendo, juridicamente, o parentesco entre pai e mãe e seu filho. Não cria, portanto, a paternidade, pois apenas visa a declarar um fato, do qual o direito tira consequências.” (DINIZ, 2011, p. 505).

Toda pessoa possui vínculo biológico de filiação com um pai e uma mãe. Entretanto, não necessariamente este vínculo corresponderá ao estabelecido pelo registro de nascimento, ou até mesmo à relação estabelecida, de fato, entre o pai e o filho, seja essa filiação havida no casamento ou não. Há tempos já se vem admitindo a desbiologização da paternidade (DIAS, 2013), garantindo-se a proteção ao vínculo sem que necessariamente haja uma identidade biológica entre os pais e o filho. Aliás, a prova do vínculo biológico nem mesmo é exigida no ato do reconhecimento voluntário, bastando a vontade de quem registra em reconhecer alguém como seu filho.

Grande parte dos problemas relacionados à filiação havida fora do casamento diz respeito ao vínculo de paternidade e não ao de maternidade. Isto porque para a maternidade vale a presunção mater semper certa est, só podendo ser contestada a maternidade presente no termo de nascimento provando-se sua falsidade, o que restringe a demanda a casos bem específicos. Além disso, a maternidade é uma condição ostensiva, e a ligação entre a mãe e o filho em razão da gestação, por si, acaba por reafirmar a presunção.

No casamento, como visto, a lei presume que a paternidade do filho é do marido da mãe, tendo em vista pressupor-se que o dever de fidelidade é cumprido naquele casamento. Mas numa relação diferente do casamento, não há presunção. Assim, no momento do reconhecimento, admite-se a possibilidade de um homem reconhecer como filho alguém que não seja seu filho biológico, por imaginar ser genitor deste, por não preferir confirmar se existe a identidade biológica, ou até mesmo por ter estabelecido com ele um vínculo afetivo, a chamada adoção à brasileira. $\mathrm{O}$ elemento afetivo, portanto, tem uma grande relevância no reconhecimento.

O destaque dado ao elemento afetivo presente na família contemporânea importa não apenas para a segurança psicológica de seus entes mas também para imputar-lhes responsabilidades uns com os outros, muitas vezes acima de qualquer outro vínculo. Desta 
maneira, aquele que reconhece voluntariamente um filho conscientemente assume responsabilidades em relação a este, ainda que o tenha reconhecido apenas por uma questão de afeto.

O reconhecimento, de acordo com o Código Civil, pode ser feito por quatro formas, estabelecidas no artigo 1609: no próprio registro de nascimento, por escritura pública ou escrito particular a ser arquivado em cartório, por testamento e por manifestação expressa perante o juiz. A única proibição na forma de se proceder ao reconhecimento é na ata do casamento. Carlos Roberto Gonçalves (2015) diz que a proibição se justifica pois o reconhecimento feito na ata de casamento levaria à dedução lógica origem extramatrimonial do filho. Tal proibição, portanto, seguiria àquela de se mencionar, no registro de nascimento, a origem da filiação.

Outras restrições concernentes ao reconhecimento dizem respeito ao reconhecimento de filho maior, e após a maioridade de filho reconhecido quando menor. Conforme preleciona o artigo 1614, o filho maior não pode ser reconhecido sem o seu consentimento e o menor pode impugnar o reconhecimento feito quando menor, no prazo decadencial de quatro anos que se seguirem à maioridade ou à emancipação.

Por disposição expressa do artigo 1610, o reconhecimento é irrevogável, ainda que feito por testamento (que é ato essencialmente revogável). Esta característica de irrevogabilidade, e também de irretratabilidade, do reconhecimento suscita algumas questões acerca da possibilidade do desfazimento deste ato.

A filiação em relação à mãe não casada é um vínculo estabelecido através do reconhecimento, porém a mãe que faz o registro, na maioria dos casos, tem, e sabe que tem, o vínculo biológico com o filho. O vínculo biológico, para a mãe, é evidente em razão da gestação. Daí a presunção mater semper certa est, ou seja, a mãe é sempre certa, também tem peso na filiação havida fora do casamento. Em decorrência disto, as formas de reconhecimento diferentes da registral, não são usuais.

No que tange ao pai, diferentemente do casamento, onde há uma presunção de fidelidade da mulher, o reconhecimento pode ocorrer sem que o homem tenha certeza de que é o pai biológico do filho. No entanto, o reconhecimento é, pela lei, irrevogável, não podendo em princípio ser desfeito caso o pai venha a saber que o filho não é o seu filho biológico.

Muito embora seja irrevogável, tem sido admitida, a ação negatória de paternidade para os casos em que o autor vivia em união estável com a genitora do filho ${ }^{3}$, aplicando-se por analogia a presunção pater is est também na união estável. Fora isto, única hipótese admitida por lei de retorno a status quo ante existente, sem que se pugne especificamente por uma 
revogação do reconhecimento, é através de uma ação anulatória de registro, na qual quem realizou o reconhecimento tem a oportunidade de alegar erro ou dolo e obter a anulação do ato praticado, desincumbindo-se da condição de pai.

Sendo o reconhecimento um ato declaratório, portanto, deveria corresponder a uma situação verdadeira. A grande questão que se impõe hoje é: a que situação verdadeira? À verdade biológica, da qual não é exigida prova? Ou a uma verdade de afeto, que busca a formalização dada pela lei? As respostas a esses questionamentos constituem boa parte da construção jurisprudencial hodierna, analisando-se, caso a caso, conjugando-se a prova pericial com a posse do estado de filho, especialmente quando baseada no dado afetivo.

\section{A POSSIBILIDAde do AJUIZAMENTO dA AÇÃO NEGATÓRIA DE PATERNIDADE NOS CASOS DE FILIAÇÃO HAVIDA EM RELAÇÕES DIFERENTES DO CASAMENTO}

O presente trabalho foi inspirado num caso concreto, que resultou numa ação que teve início no ano de 2009, e correu perante a 1. a Vara de Família da Comarca de Juiz de Fora, Minas Gerais ${ }^{4}$. Na ocasião, um pai, onze anos depois de ter reconhecido a paternidade do filho de uma mulher com quem tivera um relacionamento, ajuizou uma ação negatória de paternidade, buscando o retorno ao status quo ante à declaração de reconhecimento, alegando ter sido induzido a erro, por não saber o significado da importância do ato de reconhecimento, e alegando também não manter qualquer vínculo afetivo com o filho.

Nas argumentações do autor não havia qualquer sustentação enfática de erro ou de coação, pelas quais pudesse ser a ação julgada como se fosse uma anulação de registro. Ele basicamente sustentava que não entedia a gravidade do ato que tinha praticado. $\mathrm{O}$ argumento mais reforçado era o de que ele, na qualidade de pai registral, nunca tivera outro vínculo com o filho senão apenas o do registro, quanto mais uma relação de afeto.

O primeiro estranhamento surge em relação à adequação da ação, negatória de paternidade cumulada com retificação de registro, que seria privativa do marido da mãe ou, no máximo, do companheiro, como já vem admitindo a jurisprudência hodierna. Não tendo sido extinta a ação por falta de interesse de agir, afinal, o autor não era casado com a mãe, a

\footnotetext{
${ }^{3}$ BRASIL. Superior Tribunal de Justiça. 4. ${ }^{\text {a }}$ Turma. Recurso Especial 440394/RS (2002/0067683-0). Relator: Ministro Ruy Rosado de Aguiar. Publicado no Diário da Justiça em 10 de fevereiro de 2003, p. 221.

${ }^{4}$ Autos n. ${ }^{\circ} 0145.09 .559625-3$
} 
ação correu à revelia, tendo a juíza do caso aceitado e levado em consideração a contestação apresentada intempestivamente. Nela o requerido afirmava não ser filho biológico do autor, mas que fora registrado por este, dois anos após seu nascimento, numa época em que o autor vivera em união estável com sua mãe.

Também chama a atenção no caso o fato da ação só ter sido proposta onze anos após o registro, poucos meses após o envio de um ofício de desconto de alimento em folha de pagamento ao empregador do requerente. Tal ofício foi expedido numa ação de execução de alimentos, na qual o requerido executava alimentos acordados com o autor. $\mathrm{O}$ ajuizamento da negatória de paternidade tinha, portanto, o aparente propósito de desonerar o autor de suas obrigações.

A única prova produzida nos autos foram o depoimento pessoal do autor e o depoimento de uma testemunha, seu ora cunhado. Pelo depoimento pessoal, o autor mostrouse certo de que quando registrara o filho já era ciente que não era seu pai biológico. Além disso, sustentou que nunca tivera contato com o requerido, o que foi confirmado pela testemunha.

Acolhendo, pois, o alegado pelo pai, de que não teria havido convivência deste com o filho, o Ministério Público opinou pela procedência do pedido autoral, argumentando que a paternidade registral não implica, por si, numa paternidade socioafetiva, assim, não tendo sido estabelecida uma relação afetiva entre o pai registral e o filho, não haveria motivos para que se mantivesse o registro.

A sentença julgou o pedido improcedente em relação à alegação de erro. No entanto, acompanhou os argumentos do Ministério Público, julgando procedentes os pedidos autorais de cancelamento do registro, tendo todo seu fundamento no princípio da socioafetividade. A juíza considerou que a manutenção do vínculo registral junto com a inexistência tanto de vínculo biológico quanto de socioafetivo causaria mais danos à criança do que a extinção do vínculo.

Não houve recurso da decisão e, portanto, o nome do autor foi retirado do registro do requerido, bem como suprimido seu patronímico. Consequentemente, cessadas foram todas obrigações decorrentes da paternidade, a partir do trânsito em julgado da sentença.

Tal sentença, ainda que pudesse ter sido reformada, é curiosa, tendo em vista que o tipo de ação utilizada e as provas apresentadas para se desconstituir aquela paternidade eram bem inconsistentes para comprovar a falta de vínculo entre o pai registral e o filho. A irretratabilidade do reconhecimento foi, desta forma, posta em cheque. Entretanto, a decisão 
traz pontos interessantes a serem discutidos quando se questiona o sistema legalista de estabelecimento da filiação, por priorizar a relação de afeto e o melhor interesse da criança.

De acordo com a lei, a revogação do reconhecimento é inadmitida, até mesmo quando feita por instrumentos essencialmente revogáveis, como o testamento. Em relação ao reconhecimento feito no registro, entretanto, não seria tecnicamente correto uma revogação, mas sim um cancelamento, pedido através de ação judicial, o que corresponderia a uma retratação à declaração feita. $\mathrm{O}$ cancelamento, por motivos outros que não os vícios do ato que justificariam sua anulação, seria possível diante da regra da irrevogabilidade?

Diversos fatores devem ser levados em consideração, a começar pelo elemento subjetivo de quem realiza o reconhecimento, no momento do ato. A consciência prévia da não-paternidade impediria um pedido posterior de cancelamento, tendo em vista que ninguém pode se valer da própria torpeza? Ou este só seria possível diante de uma situação de erro, ainda que vencível, em que aquele que reconheceu não sabia se seria ou não o pai? Em quais hipóteses poderia se admitir retratação no reconhecimento?

A análise do caso sob o prisma de dois princípios é essencial para que se possa admitir ou não a desconstituição do vínculo através de uma ação negatória de paternidade. O primeiro deles, como já visto, é o princípio da afetividade.

Adriana Caldas do Rego Freitas Dabus Maluf (apud CASSETARI, 2014) traz a origem etimológica de afeto como derivada de onde o sujeito se fixa, ou seja, o afeto traz a noção de ligação com o outro, dando sentido, esta ligação, a sua existência e à relação com os outros indivíduos. Fachin (2008), esclarece que o leitmotiv, ou seja, o tema central do Direito de Família contemporâneo, não é mais vínculo matrimonial, mas o dado afetivo.

Ignorar o dado afetivo atualmente é atentar contra o princípio da dignidade humana, pois reduz as relações familiares a vínculos exclusivamente legalistas, situação não mais suportadas pelo Direito contemporâneo. Ao elevar a união estável à condição de família, a Constituição Federal consagrou o afeto, derrubando a barreira que sustentava que a única família possível, legítima, seria a formada pelo casamento. A partir daí a afetividade foi elevada a princípio, apto a proteger as relações familiares.

Em sendo assim é que existente o dado afetivo a relação de paternidade pode ser identificada, inclusive sendo possível admitir-se uma parentalidade exclusivamente socioafetiva (CASSETARI, 2014), independente de vínculos biológicos ou registrais. Desta forma, a prova da inexistência do dado afetivo seria ponto chave para a possibilidade de se desconstituir uma relação de paternidade levada a registro através de reconhecimento. 
É uma solução que pode ser perigosa. Aplicada a uma relação de filiação registral em que o pai nunca teve relação de afeto com o filho, nem vínculo biológico, mas este filho ainda se encontrando na infância, a desconstituição do vínculo talvez possa ser coerente, pois evita que o filho crie uma identidade com um pai com o qual não tem vínculo biológico nem afetivo.

Por outro lado, a mesma solução aplicada a um vínculo de filiação de um adolescente ou de um adulto, seria justa? E se o vínculo afetivo deixou de existir a partir de um dado momento da vida, mas o filho continua reconhecendo o pai como tal? Como negar a posse de estado de filho para se desconstituir a filiação? Sobre a posse do estado de filho, esclarecedoras são as palavras de Fachin:

\begin{abstract}
A relação parental em que se consolida a posse de estado de filho constitui situação jurídica que, de regra, não é mais passível de desconstituição por conta de interesses de terceiros ou mesmo por simples ato voluntário dos que integram a relação jurídica. O caráter de ordem pública do parentesco constituído pela posse de estado de filho subtrai dos sujeitos o direito de promoverem tout court a sua desconstituição voluntaria, por não mais se situar a relação no âmbito dessa autonomia privada. (FACHIN, 2008, p. 160)
\end{abstract}

Estes motivos levam a crer que, ao lado da análise da existência da afetividade, e de sua consideração como princípio, há que se tomar em conta também o princípio da paternidade responsável, principalmente quando se estabelece a posse de estado de filho.

O princípio da paternidade responsável é um dos fundamentos do planejamento familiar, juntamente com o princípio da dignidade humana, conforme dispõe o artigo 226 da Constituição Federal. Tal dispositivo garante ao homem e à mulher total liberdade no que diz respeito à formação de sua família. Segundo Maria Helena Diniz (2011, p. 38), “com isso o Constituinte veio a garantir a democratização do planejamento familiar, dando ao casal a livre decisão sobre o assunto, coibindo interferências de qualquer entidade, inclusive religiosa".

Havendo, pois, a liberdade do casal em decidir a respeito da existência ou não de filhos, e de quantos filhos terão, é imperativo que assumam a responsabilidade por estes, principalmente quando a relação de filiação se estabelece pela via do reconhecimento. $\mathrm{O}$ homem que reconhece um filho e o faz por livre e espontânea vontade, assume para com aquele filho todos os deveres decorrentes da parentalidade, como o dever de sustento, de amparo material e espiritual, de educação, alimentar etc.

Em sendo assim, a desconstituição da paternidade havida pelo reconhecimento, não pode curvar-se à busca apenas da verdade biológica e nem apenas da inexistência de vínculo 
afetivo. Outros fatores e princípios devem ser analisados no caso concreto, para que se evite decisões que privem os filhos da sua identidade parental, por mais precária que seja.

\section{CONCLUSÃO}

A constante modificação na estrutura familiar reflete de sobremaneira na origem dos vínculos de filiação. Se antes havia uma estrutura familiar matrimonial e filhos legítimos, ilegítimos e naturais, hoje há famílias e filhos, protegidos e iguais, seja qual forem suas estruturas e origens.

O estabelecimento do vínculo de paternidade, de acordo com a lei civil, continua se dando de duas maneiras: ou através de uma presunção, nos casos da filiação havida numa relação de casamento ou através do reconhecimento, nos casos da filiação ser havida numa relação diferente do casamento. A primeira, por ser estabelecida através de uma presunção, admite prova em contrário, produzida numa ação denominada ação negatória de paternidade, o que permite a desconstituição do vínculo de paternidade. Já a última é considerada pela lei civil como irrevogável, qualquer que seja a sua origem: um reconhecimento voluntário ou um resultado de ação investigatória de paternidade.

No caso da ação investigatória de paternidade, o vínculo biológico prevalece, sendo a prova do exame de DNA definitiva para seu sucesso. Já o caso do reconhecimento voluntário não exige uma prova científica prévia, e os pais reconhecem os filhos pelos mais diversos motivos, na maioria deles, por haver algum vínculo afetivo com o filho ou com a genitora deste. A paternidade por reconhecimento, como visto, é irrevogável. Entretanto, há casos em que esta tem sido questionada, com fins de se desfazer o vínculo, na qual se usa de maneira atípica a ação negatória de paternidade.

Nestes casos, a prova exclusivamente científica, em princípio, não seria suficiente para a procedência do pedido, como o é na ação negatória de paternidade em que o pai é ou era casado com a mãe. Contudo já se tem admitido a ação negatória de paternidade nos casos de união estável, concluindo-se que é possível a analogia com o casamento nestes casos.

Mas a análise também feita com base também no vínculo afetivo existente entre o pai e o filho reconhecido, bem como com base na posse de estado de filho. No caso apresentado no último capítulo deste trabalho, ainda que poucas tenham sido as provas produzidas no processo, a juíza entendeu que o pai provou a inexistência do vínculo afetivo e julgou procedente a ação para desconstituir a paternidade. 
A análise da existência do vínculo socioafetivo é primordial, pois, como visto, o tom do Direito de Família atual é dado pela afetividade. Só que utilizá-la para romper um vínculo que a lei estabelece como irrevogável é perigoso em razão de dois fatores: o primeiro, de negar-se o princípio da paternidade responsável, uma vez que o ato de reconhecimento é voluntário e nele o homem tem ciência que se torna pai daquele filho; o segundo, de negar-se a posse de estado de filho, que pode permanecer mesmo após a quebra do vínculo de afetividade.

Conclui-se, portanto, que ainda que se possa admitir a revogação da filiação havida por reconhecimento, nos casos em que não há identidade biológica, outros fatores hão se ser ponderados. Não há porque insistir-se na irrevogabilidade se o vínculo afetivo se desfez e pai e filho são dois estranhos. Também não há como admitir-se a revogabilidade a qualquer preço, visto que este pode significar para o filho a perda de um aspecto de sua identidade.

A modificação do caráter familiar, de patrimonial para eudemonista e afetivo, impõe a análise dos valores e princípios familiares a cada decisão judicial que diga respeito à constituição ou à desconstituição de vínculos familiares. Admitir-se um desejo de reversão do pai que reconhece o filho, retirando deste filho toda e qualquer expectativa de ter uma figura por ele responsável, pode ser andar na contramão dos princípios fundamentadores do Direito de Família atual. A admissão da ação negatória de paternidade para desconstituição de vínculo de filiação havida pelo reconhecimento, portanto, deve ser vista com a máxima cautela, sob pena de se banalizar o rompimento das estruturas familiares e, principalmente a desoneração das responsabilidades parentais.

\section{REFERÊNCIAS}

CASSETARI, Christiano. Multiparentalidade e paternidade socioafetiva. Efeitos Jurídicos. São Paulo: Atlas, 2014.

DIAS, Maria Berenice. Manual de direito das famílias [livro eletrônico]. São Paulo: Editora Revista dos Tribunais, 2013.

DINIZ, Maria Helena. Curso de Direito Civil Brasileiro. Volume 5: Direito de Família. São Paulo: Saraiva, 2011.

FACHIN, Luiz Edson. Estabelecimento da filiação e paternidade presumida. Porto Alegre: Fabris, 1992. 2008 .

Questões de Direito Civil Brasileiro Contemporâneo. Rio de Janeiro: Renovar,

GONÇALVES, Carlos Roberto. Direito civil brasileiro, volume VI: direito de família. São 
Paulo: Saraiva, 2008.

FRANÇA, Rubens Limongi. Instituições de direito civil. São Paulo: Saraiva, 1999.

LEITE, Eduardo de Oliveira Leite. Direito Civil Aplicado: direito de família. São Paulo: Revista dos Tribunais, 2005.

MIRANDA, Francisco Cavalcanti Pontes de. Tratado de direito privado, tomo IX: direito de família: direito parental. Direito protetivo. Rio de Janeiro: Editor Borsoi, 1954.

PEREIRA, Caio Mario da Silva. Instituições de Direito Civil, volume V. Rio de Janeiro: Forense, 1996.

SILVA, Marcos Alves da. Da monogamia: a sua superação como princípio estruturante do direito de família. Curitiba: Juruá, 2013.

TARTUCE, Flávio. Direito Civil, v.5: Direito de Família. Rio de Janeiro: Forense, 2016.

VENOSA, Sílvio de Salvo. Direito Civil, volume VI: Direito de família. São Paulo: Atlas, 2011.

VILELLA, João Baptista. Desbiologização da paternidade. Revista da Faculdade de Direito da Universidade Federal de Minas Gerais. Belo Horizonte, ano XXVII, n. ${ }^{\circ}$ 21, maio 1979. Disponível em http://www.direito.ufmg.br/revista/index.php/revista/article/view/1156. Acesso em 20 fev. 2016. 